\title{
Effects of metals on nitrogen fixation and denitrification in slurries of anoxic saltmarsh sediment $^{*}$
}

\author{
Jennifer Slater and Douglas G. Capone \\ Marine Sciences Research Center, State University of New York, Stony Brook, New York 11794, USA
}

\begin{abstract}
The effect of metals on nitrogen fixation, as measured by acetylene reduction, and on denitrification, as determined by nitrous oxide accumulation in the presence of acetylene (acetylene blockage), was examined in short-term experiments with saltmarsh sediments. At concentrations of $1000 \mathrm{ppm}$ (weight metal : weight dry sediment), $\mathrm{HgCl}_{2}, \mathrm{PbCl}_{2}, \mathrm{CdCl}_{2}, \mathrm{ZnSO}_{4}, \mathrm{CuCl}_{2}, \mathrm{~K}_{2} \mathrm{Cr}_{2} \mathrm{O}_{7}, \mathrm{~K}_{2} \mathrm{CrO}_{4}$, and $\mathrm{Na}_{2} \mathrm{MoO}_{4}$ decreased acetylene reduction throughout the experiments by more than $30 \% . \mathrm{FeCl}_{3}$ decreased it to a lesser extent, while $\mathrm{NiCl}_{2}$ greatly stimulated nitrogenase activity. Initial rate of nitrous oxide production was inhibited by $\mathrm{HgCl}_{2}, \mathrm{PbCl}_{2}, \mathrm{NiCl}_{2}, \mathrm{~K}_{2} \mathrm{Cr}_{2} \mathrm{O}_{7}, \mathrm{~K}_{2} \mathrm{CrO}_{4}, \mathrm{ZnSO}_{4}, \mathrm{CuCl}_{2}, \mathrm{FeCl}_{3}$, and $\mathrm{CdCl}_{2}$, but maximum production was stimulated substantially by $\mathrm{PbCl}_{2}, \mathrm{~K}_{2} \mathrm{Cr}_{2} \mathrm{O}_{7}$, and $\mathrm{K}_{2} \mathrm{CrO}_{4}$, and somewhat by $\mathrm{Na}_{2} \mathrm{MoO}_{4}, \mathrm{ZnSO}_{4}$, and $\mathrm{CuCl}_{2}$. In contrast, $\mathrm{NiCl}_{2}$ depressed both initial and maximum nitrous oxide production. Lower levels of $\mathrm{Ni}$ and $\mathrm{Hg}(10$ and $100 \mathrm{ppm})$ caused effects that were intermediate between $1000 \mathrm{ppm}$ and controls. We conclude that metal pollution could considerably alter nitrogen dynamics in marine sediments, at least in the short term; and could have repercussions on water-column productivity.
\end{abstract}

\section{INTRODUCTION}

Coastal marine sediments are a major source of combined nitrogen and play an important part in controlling water-column productivity (Nixon, 1981). The abundant nutrients found in the sediments are formed partly by microbial degradation of organic material. For nitrogen, other microbial transformations occur in the sediments: nitrification may occur in aerobic zones (Henriksen et al., 1981), while denitrification (Sorensen, 1978) and nitrogen fixation (Capone, 1983) may be important in anaerobic areas. Most organisms need to take up nitrogen in a combined form and are therefore ultimately dependent on nitrogen-fixing bacteria (Burns and Hardy, 1975). Conversely, in situ denitrification is one of the major processes decreasing the supply of available nitrogen. Thus the sediments may act either as a source or a sink of combined nitrogen. Marine sediments are also sites of accumulation of many of the anthropogenic pollutants entering the ocean. Increasing occurrence of heavy metals in sediments has been documented (Williams et al., 1978);

\footnotetext{
- Contribution \# 412 of the Marine Sciences Research Center
}

some of the metals of immediate concern are mercury, lead, cadmium, chromium, copper, zinc, and nickel (Greig and McGrath, 1977). The effect of these toxicants on microbial activity, and in particular on nitrogen transformations, is not well known. We report here the results of our recent efforts to assess the effects of several environmentally significant metals on nitrogen fixation and denitrification in anoxic saltmarsh sediments.

\section{MATERIALS AND METHODS}

Sediment was obtained in aluminum core tubes of $2.5 \mathrm{~cm}$ diameter from Spartina alterniflora communities in Flax Pond, a saltmarsh on Long Island, New York. The sediment was saltmarsh peat, with organic content ranging from 10 to $30 \%$ (loss on ignition, Armentano and Woodwell, 1975); although much of this was refractory plant material. Sediment was taken immediately to the laboratory and the top $10 \mathrm{~cm}$ of the core were homogenized in a Waring blender with deoxygenated filtered seawater in the ratio $2: 1$ (seawater: sediment, $v: v$ ). The resulting slurry was 
screened through a $2 \mathrm{~mm}$ sieve. Fifty $\mathrm{ml}$ aliquots were pipetted into $125 \mathrm{ml}$ Erlenmeyer flasks, which were immediately stoppered. Throughout setup, the slurry was continuously gassed with oxygen-free nitrogen. The flasks were placed in a water bath and incubated with shaking at $25^{\circ} \mathrm{C}\left( \pm 1^{\circ}\right)$, and all additions and withdrawals were made by syringe through the stoppers.

Nitrogen fixation was assessed by acetylene reduction (Capone and Taylor, 1980), and denitrification potential by the accumulation of nitrous oxide in the presence of acetylene (acetylene blockage, Sorensen, 1978). Acetylene was added to the gas phase of the incubations to final concentration of $20 \%(\mathrm{v}: \mathrm{v})$. Nitrate was added as potassium nitrate solution; lead, mercury, copper, nickel, cadmium, and iron as the chlorides, zinc as the sulphate, chromium as chromate and dichromate, and molybdenum as molybdate. All additions were kept to $0.5 \mathrm{ml}$ except for $\mathrm{PbCl}_{2}(1 \mathrm{ml})$. Concentrations were calculated as nmoles $\mathrm{ml}^{-1}$ of slurry for nitrate, and as weight of metal (dry weight of sediment) ${ }^{-1}$ for metals. Control flasks were amended with an equal volume of deionized distilled water; 3 replicates of each treatment were run. At the end of the experiment, gas phase volumes were measured for each flask, and the dry weight of sediment was determined after drying at $105^{\circ} \mathrm{C}$ to constant weight.

Ethylene and nitrous oxide concentrations were measured by gas chromatography on a Perkin-Elmer Sigma 2B gas chromatograph. Samples of $100 \mu$ were withdrawn from the gas phase periodically and injected onto a $3 \mathrm{~m}, 3 \mathrm{~mm}$ O. D., 80 to 100 mesh Porapak-R column. Nitrous oxide was determined by thermal conductivity and ethylene by flame ionization, with detectors connected in series; carrier gas used was helium at $30 \mathrm{ml} \mathrm{min}^{-1}$ and oven temperature was $60^{\circ} \mathrm{C}$. The detectors were calibrated with gas standards at the same temperature as the samples, in concentrations from $1 \mathrm{ppm}$ to $1 \%$; a standard close to the concentration in the incubation flasks was checked before and after every sample run. Concentrations of ethylene and nitrous oxide in the gas phase were corrected for solubility.

Effects of metals were assessed by comparisons with control flasks. The initial rate in controls was determined by least squares regression of the linear portion of the time course of gas production, excluding the lag period if it existed; the initial rate in the experimental flasks was then taken as the rate over the same period. In the acetylene reduction experiments, ethylene production at $72 \mathrm{~h}$ in experimental flasks was also compared with that in control flasks. In the acetylene blockage experiments, the maximum production noted during the experiment was compared between experimental and control flasks. Means of experimental and control flasks were compared for statistical significance using a t-test.

Concentrations of copper, lead, chromium, and nickel were determined by atomic absorption spectrometry. Ten cm cores from the same site were ovendried at $105^{\circ} \mathrm{C}$, extracted with concentrated $\mathrm{HCl}$ $\mathrm{HNO}_{3}(1: 1)$ for $4 \mathrm{~h}$ at $95^{\circ} \mathrm{C}$, and the metals determined on a Perkin-Elmer model 403 atomic absorption spectrophotometer.

\section{RESULTS}

From experiments on the effects of added nitrate on rates of acetylene reduction and nitrous oxide production (Slater and Capone, in prep.), it was determined that a concentration of $100 \mu \mathrm{M}$ added nitrate in the slurry would reliably produce large enough amounts of nitrous oxide to be precisely measurable, while never reducing ethylene production by more than $19 \%$. One hundred $\mu \mathrm{M}$ nitrate was therefore added routinely to each incubation flask. Controls with filtered seawater only, with autoclaved homogenates, and without added acetylene were conducted periodically and showed no production of either ethylene or nitrous oxide. Acetylene concentration was routinely monitored and did not decrease during any experiment reported here.

Ethylene production in controls was usually linear from zero time for 15 to $26 \mathrm{~h}$; after this time, the rate of ethylene production slowed down, but in no case did it cease even after 2 wk incubations (Fig. 1)

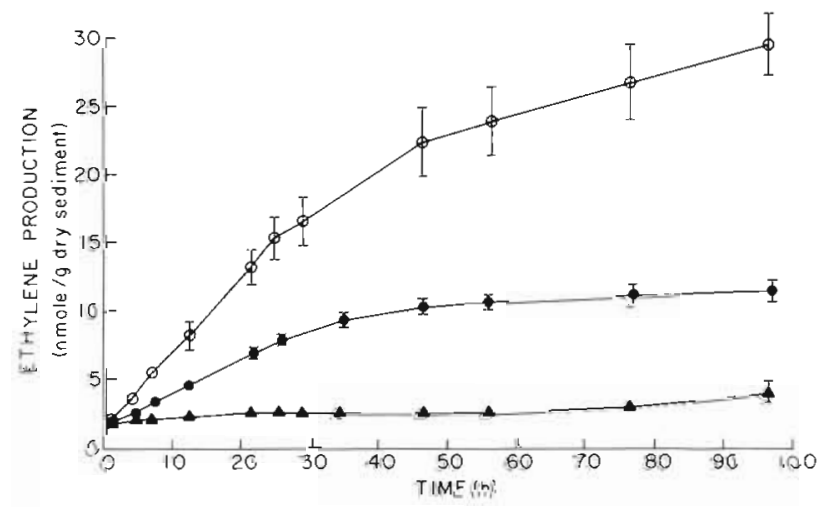

Fig. 1. Ethylene production 26 Jan 1982. Points are means of triplicate samples and error bars are standard errors of means controls; 1000 ppm Mo as $\mathrm{Na}_{2} \mathrm{MoO}_{4}$; $1000 \mathrm{ppm} \mathrm{Cr}$ as $\mathrm{K}_{2} \mathrm{Cr}_{2} \mathrm{O}_{7}$

In controls a lag of 1 to $3 \mathrm{~h}$ was observed before nitrous oxide was detected in all but 2 experiments. In all controls, nitrous oxide production rate was constant by $5 \mathrm{~h}$ and continued so for 8 to $21 \mathrm{~h}$; there was then a period of 6 to $20 \mathrm{~h}$ during which nitrous oxide concentration increased more slowly or remained relatively 


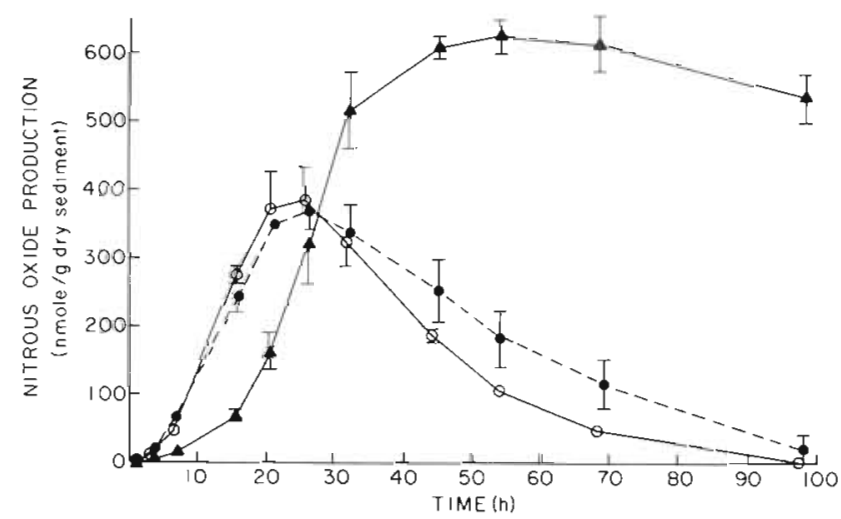

Fig. 2. Nitrous oxide production $23 \mathrm{Feb}$ 1982. Points are means of triplicate samples and error bars are standard errors of means. O control; $\bullet 1000 \mathrm{ppm} \mathrm{Fe}$ as $\mathrm{FeCl}_{3} ; 1000 \mathrm{ppm} \mathrm{Cr}$ as $\mathrm{K}_{2} \mathrm{CrO}_{4}$

constant, followed by a decrease in nitrous oxide concentration (Fig. 2). An experiment with chloramphenicol added at $10 \mu \mathrm{g} \mathrm{ml}^{-1}$ showed the same time course, as did experiments with $100 \%$ acetylene atmosphere (Slater and Capone, in prep.). Addition of nitrate after the nitrous oxide concentration started to decrease had no effect in 3 experiments.

All control and experimental incubations were run in triplicate. The coefficient of variation among triplicates was less than $10 \%$ in $76 \%$ of cases.

The effects of $1000 \mathrm{ppm} \mathrm{Ni}, \mathrm{Zn}$, and $\mathrm{Cu}$ (Fig. 3) and of various concentrations of $\mathrm{Hg}$ (data not shown) on

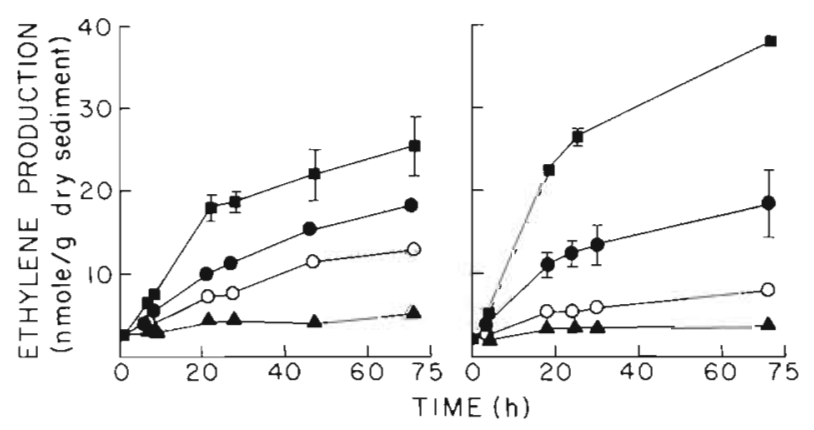

Fig. 3. Ethylene production on 17 Nov 1981 (left) with no added nitrate and on 8 Dec 1982 (right) with $100 \mu \mathrm{M}$ added nitrate. Points are means of triplicate samples and error bars are standard errors of means. - controls; 01000 ppm Zn; \ $1000 \mathrm{ppm} \mathrm{Cu}$ - $1000 \mathrm{ppm} \mathrm{Ni}$

ethylene production were similar in the presence and absence of nitrate. That is, when each treatment was compared to the control incubation within the same experiment, both the direction (stimulation or inhibition) and the hierarchy of effects were similar, whether or not nitrate had been added to the sediment.

Initial rate of ethylene production in controls varied from 0.12 nmole $\mathrm{g}^{-1} \mathrm{~h}^{-1}$ to $1.3 \mathrm{nmole}^{-1} \mathrm{~h}^{-1}$, and $72 \mathrm{~h}$ production from 6.7 nmole $\mathrm{g}^{-1}$ to 36 nmole $\mathrm{g}^{-1}$. For nitrous oxide in controls, initial rate of production was between 5.4 nmole $\mathrm{g}^{-1} \mathrm{~h}^{-1}$ and 36 nmole $\mathrm{g}^{-1} \mathrm{~h}^{-1}$; and maximum production was between $21 \mathrm{nmole}^{-1}$ and 490 nmole $\mathrm{g}^{-1}$. Experimental incubations were normalized to controls to allow comparisons between experiments on different days (Tables 1 and 2).

Table 1. Summary of effects of metals in various experiments on production of ethylene.

\begin{tabular}{|c|c|c|c|}
\hline & \multirow[b]{2}{*}{ Metal } & \multicolumn{2}{|c|}{ Ethylene production } \\
\hline & & \multicolumn{2}{|c|}{$\begin{array}{l}\text { (Ratio of experimental to } \\
\text { control incubations) }\end{array}$} \\
\hline $\operatorname{Zn}(2)$ & $1000 \mathrm{ppm}$ & $0.43 \pm 0.02$ & $0.56 \pm 0.10$ \\
\hline $\mathrm{Cu}(3)$ & $1000 \mathrm{ppm}$ & $0.20 \pm 0.01$ & $0.15 \pm 0.03$ \\
\hline $\operatorname{Cr}(5)$ & $1000 \mathrm{ppm}$ & $0.07 \pm 0.02$ & $0.06 \pm 0.02$ \\
\hline $\mathrm{Mo}(2)$ & $1000 \mathrm{ppm}$ & $0.44 \pm 0$ & $0.35 \pm 0$ \\
\hline $\mathrm{Fe}(2)$ & $1000 \mathrm{ppm}$ & $0.94 \pm 0.16$ & $0.74 \pm 0.05$ \\
\hline $\mathrm{Cd}(2)$ & $1000 \mathrm{ppm}$ & $0.34 \pm 0.14$ & $0.33 \pm 0.14$ \\
\hline $\mathrm{Ni}(1)$ & $10 \mathrm{ppm}$ & 1.1 & 1.2 \\
\hline $\mathrm{Ni}(1)$ & $100 \mathrm{ppm}$ & 2.0 & (1) \\
\hline $\mathrm{Ni}(3)$ & $1000 \mathrm{ppm}$ & $2.4 \pm 0.64$ & $2.2 \pm 0.46$ \\
\hline $\mathrm{Pb}(4)$ & $10 \mathrm{ppm}$ & $1.2 \pm 0.23$ & $1.2 \pm 0.20$ \\
\hline $\mathrm{Pb}(3)$ & $100 \mathrm{ppm}$ & $0.83 \pm 0.09$ & $0.90 \pm 0.10$ \\
\hline $\mathrm{Pb}(4)$ & $1000 \mathrm{ppm}$ & $0.70 \pm 0.11$ & $0.64 \pm 0.10$ \\
\hline $\mathrm{Hg}(2)$ & $10 \mathrm{ppm}$ & $0.98 \pm 0.02$ & $0.95 \pm 0.04$ \\
\hline $\mathrm{Hg}(2)$ & $100 \mathrm{ppm}$ & $0.89 \pm 0$ & $0.88 \pm 0.02$ \\
\hline $\mathrm{Hg}(3)$ & $1000 \mathrm{ppm}$ & $0.53 \pm 0.05$ & $0.57 \pm 0.06$ \\
\hline \multicolumn{4}{|c|}{$\begin{array}{l}\text { Number in parentheses after metal indicates number of } \\
\text { experiments; ratio is presented as mean } \pm \text { standard error } \\
\text { for pooled experiments with number in parentheses indi- } \\
\text { cating number of individual experiments where triplicate } \\
\text { dosed flasks differed from controls at or above the } 95 \% \\
\text { confidence level }\end{array}$} \\
\hline
\end{tabular}

The effects of all metals examined on ethylene production were the same for both initial rate and final production. $\mathrm{Pb}, \mathrm{Hg}, \mathrm{Cu}, \mathrm{Zn}, \mathrm{Cr}, \mathrm{Mo}$, and $\mathrm{Cd}$ at 1000 ppm all caused marked inhibition, while nickel stimulated nitrogenase activity considerably. Iron caused slight inhibition of both initial rate and $72 \mathrm{~h}$ production, although these results were statistically significant in only 1 of the 2 experiments (Table 1 ).

Most metals examined ( $\mathrm{Hg}, \mathrm{Pb}, \mathrm{Ni}, \mathrm{Cr}, \mathrm{Zn}, \mathrm{Cu}, \mathrm{Fe}$, and $\mathrm{Cd}$ at $1000 \mathrm{ppm}$ ) depressed the initial rate of nitrous oxide production; Mo had no significant effect. Only Ni significantly depressed maximum levels of nitrous oxide; $\mathrm{Pb}$ and $\mathrm{Cr}$ stimulated maximum nitrous oxide concentration considerably and Mo somewhat; $\mathrm{Zn}$ and $\mathrm{Cu}$ appeared to stimulate consistently but the results in individual experiments were statistically not significant; the same was true for the depression caused by Fe. Cadmium and $\mathrm{Hg}$ were most inconsistent, causing either stimulation or inhibition of max- 
Table 2. Summary of effects of metals in various experiments on production of nitrous oxide ${ }^{*}$

\begin{tabular}{|c|c|c|c|}
\hline \multirow{2}{*}{\multicolumn{2}{|c|}{ Metal }} & \multicolumn{2}{|c|}{ Nitrous oxide production } \\
\hline & & \multicolumn{2}{|c|}{$\begin{array}{l}\text { (Ratio of experimental to } \\
\text { control incubations) }\end{array}$} \\
\hline $\operatorname{Zn}(1)$ & $1000 \mathrm{ppm}$ & 0.58 (1) & 1.2 \\
\hline $\mathrm{Cu}(2)$ & $1000 \mathrm{ppm}$ & $0.73 \pm 0.17$ & $1.1 \pm 0$ \\
\hline $\mathrm{Cr}(5)$ & $1000 \mathrm{ppm}$ & $0.28 \pm 0.07$ & $1.9 \pm 0.11$ \\
\hline Mo (2) & $1000 \mathrm{ppm}$ & $1.1 \pm 0.10$ & $1.2 \pm 0$ \\
\hline $\mathrm{Fe}(2)$ & $1000 \mathrm{ppm}$ & $0.74 \pm 0.03$ & $0.94 \pm 0$ \\
\hline $\mathrm{Cd}(2)$ & $1000 \mathrm{ppm}$ & $0.23 \pm 0.07$ & $1.1 \pm 0.25$ \\
\hline $\mathrm{Ni}(1)$ & $10 \mathrm{ppm}$ & 0.89 & 0.98 \\
\hline Ni (1) & $100 \mathrm{ppm}$ & 0.81 (1) & 0.85 \\
\hline $\mathrm{Ni}(2)$ & $1000 \mathrm{ppm}$ & $0.14 \pm 0.14$ & $0.35 \pm 0.35$ \\
\hline $\mathrm{Pb}(4)$ & $10 \mathrm{ppm}$ & $1.2 \pm 0.26$ & $1.2 \pm 0.12$ \\
\hline $\mathrm{Pb}(3)$ & $100 \mathrm{ppm}$ & $1.2 \pm 0.16$ & $1.2 \pm 0.12$ \\
\hline $\mathrm{Pb}(4)$ & $1000 \mathrm{ppm}$ & $0.60 \pm 0.15$ & $1.6 \pm 0.39$ \\
\hline $\mathrm{Hg}(1)$ & $10 \mathrm{ppm}$ & 0.66 & 0.63 \\
\hline $\mathrm{Hg}(1)$ & $100 \mathrm{ppm}$ & 0.48 & 0.62 \\
\hline $\mathrm{Hg}(2)$ & $1000 \mathrm{ppm}$ & $0.49 \pm 0.25$ & $0.97 \pm 0.12$ \\
\hline \multicolumn{4}{|c|}{$\begin{array}{l}\text { - Number in parentheses after metal indicates number of } \\
\text { experiments; ratio is presented as mean } \pm \text { standard error } \\
\text { for pooled experiments, with number in parentheses indi- } \\
\text { cating number of individual experiments in which tripli- } \\
\text { cate experimental flasks differed significantly from con- } \\
\text { trols at or above the } 95 \% \text { confidence limit }\end{array}$} \\
\hline
\end{tabular}

imum production of nitrous oxide in different experiments (Table 2).

There were no significant differences between $\mathrm{Cr}$ added as chromate or as dichromate on either ethylene or nitrous oxide production. In experiments with $\mathrm{Ni}$, $\mathrm{Cr}, \mathrm{Zn}$, and $\mathrm{Cd}$, nitrous oxide persisted with little or no decrease in concentration for 6 or more days, in contrast to the disappearance in controls, usually by $72 \mathrm{~h}$. This effect is shown in Fig. 2 for $\mathrm{Cr}$ and in Fig. 4 for Ni. Mercury and $\mathrm{Pb}$ also caused slight persistence of the nitrous oxide ( 10 to $20 \mathrm{~h}$ over controls). The initial lag before nitrous oxide was detected was increased by 1 to $2 \mathrm{~h}$ over controls by $\mathrm{Ni}, \mathrm{Cr}, \mathrm{Cd}, \mathrm{Hg}$, and $\mathrm{Pb}$.

The effects of 10 and $100 \mathrm{ppm}$ of $\mathrm{Pb}, \mathrm{Hg}$, and Ni were also examined. For $\mathrm{Ni}$, there was stimulation of ethylene production at all levels, increasing with increasing amounts of nickel, though results at $10 \mathrm{ppm}$ were significant only at the $90 \%$ confidence level. Both initial rate and maximum production of nitrous oxide were increasingly inhibited with increasing concentrations of $\mathrm{Ni}$, though again the results at $10 \mathrm{ppm}$ were significant at $90 \%$ but not at $95 \%$ probability (Fig. 4 ).

Concentration-dependent inhibition of production of both ethylene (initial rate and $72 \mathrm{~h}$ production) and nitrous oxide (initial rate) was noted with 10,100 , and $1000 \mathrm{ppm} \mathrm{Hg}$. The effect of $\mathrm{Hg}$ on maximum nitrous oxide production was variable as previously noted,
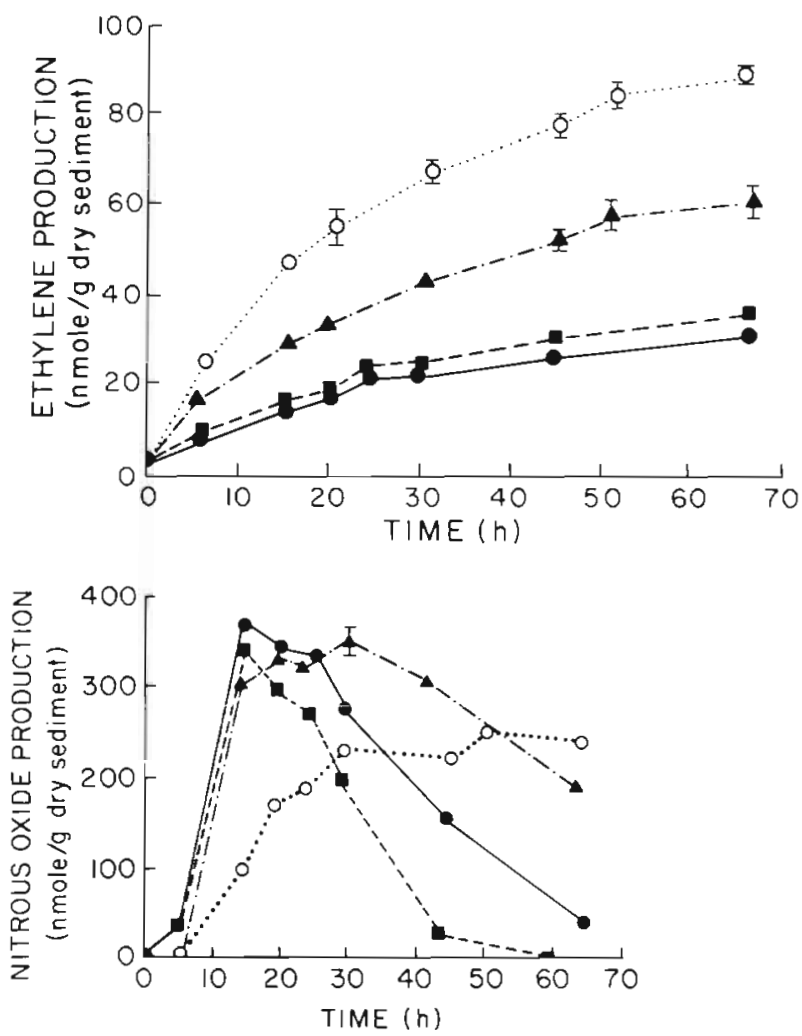

Fig. 4. Effects of Ni on production of ethylene (top) and nitrous oxide (bottom). controls - $10 \mathrm{ppm}_{\mathrm{i}}$ ॥ $100 \mathrm{ppm} ; 01000 \mathrm{ppm}$

sometimes stimulating and sometimes inhibiting. Effects of lower concentrations of $\mathrm{Pb}$ were also ambiguous. Ten $\mathrm{ppm} \mathrm{Pb}$ appeared to stimulate production of both ethylene and nitrous oxide, but the results were not statistically significant in all experiments. One hundred $\mathrm{ppm} \mathrm{Pb}$ inhibited ethylene production but Iess than did $1000 \mathrm{ppm}$; the effect of $100 \mathrm{ppm} \mathrm{Pb}$ on nitrous oxide production was to stimulate slightly both initial rate and maximum production.

Representative metal concentrations for the top $10 \mathrm{~cm}$ of sediment at the study site were as follows: $\mathrm{Cu}$, $71 \pm 6 \mathrm{ppm}, \mathrm{Pb}, 47 \pm 2 \mathrm{ppm}, \mathrm{Cr}, 30 \pm 2 \mathrm{ppm}, \mathrm{Ni}, 31 \pm$ $5 \mathrm{ppm}$, where the error is the standard error for 5 replicate samples.

\section{DISCUSSION}

Nitrogen is the limiting nutrient in several salt marshes (Valiela and Teal, 1979; DeLaune and Patrick, 1980). The magnitude of bacterial input and output of nitrogen suggests that nitrogen-transforming organisms may be of crucial importance in the overall functioning of the marsh (Haines et al., 1977; Valiela and Teal, 1979). Marshes near developed areas are susceptible to nutrient loading and toxification. It has 
been suggested that salt marshes could be used as nitrogen sinks in the presence of nitrate pollution (Van Raalte et al., 1974), and as part of sewage treatment systems (Giblin et al., 1980).

Studies of the effects of metals on nitrogen-transforming bacteria are not extensive. Copper, even at very low concentrations $\left(5 \mu \mathrm{gl} \mathrm{l}^{-1}\right)$, has been shown to eliminate nitrogen fixation by cyanobacteria after $3 \mathrm{~d}$ of exposure (Horne and Goldman, 1974). However, another study found no correlation between concentrations of $\mathrm{Cd}, \mathrm{Pb}, \mathrm{Zn}$, and $\mathrm{Cu}$ in soils and acetylene reduction activity (Rother et al., 1982). Sewage sludge (with high metal content) decreases the denitrification potential of a saltmarsh and this effect is attributed to some toxic component of the sludge (Sherr and Payne, 1981).

In our study, all the metals screened except. $\mathrm{Ni}$ caused inhibition of nitrogenase activity as measured by acetylene reduction. The smallest effect was observed with iron, which is already present in the sediments in much higher concentration than the other metals, and in fact greater than the addition (King et al., 1982).

The effects on denitrification were in several cases not statistically significant because of high variability. The variability in any one experiment appeared to be related to the slightly different lag time in each replicate; often the replicates seemed to follow the same time course but were slightly displaced from one another. We have recently determined that this was due to variable residual oxygen concentrations in the flasks (Slater and Capone, in prep.). However, in spite of this variability, for many of these metals $(\mathrm{Cr}, \mathrm{Pb}, \mathrm{Zn}$, $\mathrm{Cu}, \mathrm{Mo}$ ), it was possible to detect both an initial inhibition and a later increase of denitrification. Nickel, and to a much lesser extent $F e$, decreased both initial and maximum nitrous oxide production. Although Fe(III) can act as an electron-acceptor for nitrate-reducing bacteria, this occurs only when nitrate is depleted (Sorensen, 1982), and in any case the effect of Fe here was very small.

$\mathrm{Cr}, \mathrm{Pb}, \mathrm{Zn}, \mathrm{Cu}$, and $\mathrm{Mo}$ - the metals that appear to stimulate denitrification - were observed to inhibit sulfate reduction and stimulate methanogenesis by Capone et al. (1983); they speculated that the stimulation of methane production might be caused by release of substrate competition with sulfate respirers. This argument might be extended to explain the increase in denitrification. Denitrifiers can use a much wider array of organic substrates than can sulfate reducers (Nedwell, 1982), and their potential growth yield is greater, but their importance as carbon oxidizers in anoxic sediments is usually limited by lack of nitrate. In these systems, where sufficient nitrate is added, it is possible that the denitrifiers, if metal-resistant themselves, could have taken advantage of surplus organic substrates resulting from inhibition of sulfate respirers.

For $\mathrm{Cr}$, the inhibition of acetylene reduction and the final stimulation of nitrous oxide production were both large. No difference was observed whether the Cr was added as chromate or as dichromate; in fact the chemical equilibrium between chromate and dichromate depends only on $\mathrm{pH}$. Cr (VI) has been reported to be toxic to Salmonella typhimurium whereas Cr (III) is not (Petrilli and Deflora, 1977); when $\mathrm{H}_{2} \mathrm{~S}$ is present, Cr (VI) is reduced to $\mathrm{Cr}$ (III) and then precipitated (Smillie et al., 1981). Here, however, either the Cr (VI) was not reduced or the $\mathrm{Cr}$ (III) itself had a marked effect on the nitrogen-cycling bacteria.

Molybdenum caused considerable inhibition of nitrogenase activity. This is in agreement with the results of Nedwell and Aziz (1980), who found that addition of molybdate to saltmarsh sediments reduced acetylene reduction activity. The effect is presumably due to inhibition of sulphate respirers by molybdenum (Oremland and Taylor, 1978). In contrast, molybdenum is known to stimulate nitrogenase activity in legumes (Mulder et al., 1977).

The disappearance of the nitrous oxide measured during the acetylene blockage technique has been noted previously, although on a longer time scale than in these experiments (Yeomans and Beauchamp, 1978; Van Raalte and Patriquin, 1979). The incomplete blockage has been attributed to high sulfide concentrations (Tam and Knowles, 1979), or low nitrate concentrations (Kaspar et al., 1981; Kaspar, 1982). However, the nitrate concentrations in these experiments $(100 \mu \mathrm{M})$ were well above those cited for incomplete blockage by Kaspar et al. (1981) (10 $\mu \mathrm{M})$ and Kaspar (1982) (1 $\mu \mathrm{M})$.

The disappearance of the nitrous oxide may indicate the presence in this sediment of acetylene-resistant denitrifiers, or some other nitrous-oxide consuming process (Slater and Capone, in prep.). The technique is used here as a comparative measure only, and not to assess true denitrification rates. However, some metals $(\mathrm{Cr}, \mathrm{Ni}, \mathrm{Zn}, \mathrm{Cd})$ inhibit the consumption of nitrous oxide, and their effect on nitrous oxide accumulation must therefore be considered as the net result of the effects on production and consumption. In 2 cases ( $\mathrm{Cr}$, $\mathrm{Zn}$ ) the apparent stimulation of nitrous oxide production could be caused solely by an inhibition of consumption. For $\mathrm{Ni}$, however, while $\mathrm{N}_{2} \mathrm{O}$ consumption did not occur, production was decreased, and for $\mathrm{Cd}$ production was statistically similar to control values. For other metals $(\mathrm{Pb}, \mathrm{Cu}, \mathrm{Mo})$ no effect on the $\mathrm{N}_{2} \mathrm{O}$ consuming process was apparent, although maximum $\mathrm{N}_{2} \mathrm{O}$ production was stimulated. We are currently investigating the phenomenon of nitrous oxide disappearance and the effect on it of various metals. 
The results with lower concentrations of the metals were more difficult to interpret; $10 \mathrm{ppm} \mathrm{Pb}$, for instance, may not represent a significant perturbation of a system already containing $47 \mathrm{ppm}$. However, for $\mathrm{Ni}$, even though the marsh concentration was $31 \mathrm{ppm}$, an apparent effect was observed even at $10 \mathrm{ppm}$ (with $90 \%$ probability). The effect of all 3 concentrations of $\mathrm{Ni}$ on acetylene reduction was opposite in direction from that of any other metal, and Ni was the only metal to depress maximum nitrous oxide production significantly. Nickel has been shown to be required by one methanogen (Diekert et al., 1980); the results of several parallel experiments with 100 and $1000 \mathrm{ppm} \mathrm{Ni}$ but without acetylene (data not reported here) showed no evidence of a parallel stimulation of methane production (see also Capone et al., 1983) and did not suggest a link between methanogens and nitrogen fixation.

Precipitation as sulfide or as hydroxy complexes may reduce the availability of the metals to organisms. However, the speciation of metals, and the active form with respect to observed effects on sediment bacteria, is complex and poorly understood in marine sediments. Copper concentrations in a saltmarsh have been related to sulfide formation, but complexes with organic-sulfur ligands are also important (Boulegue et al., 1982). Other work suggests that larger proportions of $\mathrm{Pb}, \mathrm{Cd}$, and $\mathrm{Cu}$ are present in the dissolved form in an estuarine sediment than consideration of sulfide precipitation would predict (Khalid et al., 1978). Large percentages of $\mathrm{Cd}$ and $\mathrm{Cu}$ have also been shown to be present in dissolved form in a saltmarsh (Lion and Leckie, 1982). The magnitudes of the effects reported here did not show any correlation with sulfide solubilities (Butler, 1964). Binding to organic matter may be the most important controlling factor (Gadd and Griffiths, 1978); and the effect of this on bioavailability is not simple (Wallace, 1982; Ortner et al., 1983). Other complicating factors include adsorption onto inorganic particles and competition by other ions present in much larger quantities (e.g. $\mathrm{Mg}$ and $\mathrm{Ca}$ )

In most cases, 1000 ppm of a given metal was used, which may seem a high concentration. However, high levels of metals have been reported from sediments in several areas, for example, up to $1230 \mathrm{ppm} \mathrm{Cu}$ and 990 ppm Pb in Raritan Bay, 1530 ppm Zn off California (Greig and McGrath, 1977), and 760 ppm Cr in a Scottish loch (Farmer, 1983). Sewage sludge may contain $>1000$ ppm $\mathrm{Zn}$ and $\mathrm{Fe}$, and hundreds of $\mathrm{ppm} \mathrm{Pb}$ and $\mathrm{Cu}$ (Sherr and Payne, 1981), and high percentages of these metals are retained by saltmarsh sediments to which the sludge is applied (Giblin et al, 1980). Metals in industrial effluents also accumulate in nearby sediments and cause very high concentrations (Carmody et al., 1973; Ward and Young, 1981).

Metals such as $\mathrm{Pb}, \mathrm{Cu}, \mathrm{Zn}, \mathrm{Cr}$, which inhibit nit- rogenase activity but apparently increase denitrification, and $\mathrm{Ni}$, which stimulates nitrogenase but inhibits denitrification, affect both the source and the sink of combined nitrogen and would have a double tendency to alter the pool of bound nitrogen. The experiments reported here suggest that elevated metal levels, such as occur in sewage sludge, or are already found in some estuarine sediments, can cause disruption of the natural balance of nitrogen cycling in the sediments, and therefore have the potential to affect the whole water column. The recent recognition of the great importance of benthic activity to the productivity of the overlying water (e.g. Nixon, 1981) suggests the need for concern at the effects of anthropogenic disruption of the sediment system.

Acknowledgements. We thank John Budin, Dwight Reese, Ron Kiene, Thomas Wilson and Glenn Lopez for their comments and assistance on various aspects of this study. In particular, we thank Dave Hirschberg for metal analyses.

A Graduate Fellowship was awarded to J. S. from the Jessie Smith Noyes Foundation. Financial support was also provided by the Environmental Protection Agency (Grant R809475-01-0), the Hudson River Foundation (Grant 14-83B12), the National Science Foundation (Grant OCE-82-00157), and the National Oceanic and Atmospheric Administration (Grant NA-80-RAD-0057).

\section{LITERATURE CITED}

Armentano, T. V., Woodwell, G. M. (1975). Sedimentation rates in a Long Island marsh determined by ${ }^{210} \mathrm{~Pb}$ dating Limnol. Oceanogr. 20: 452-456

Boulegue, J., Lord III, C. J., Church, T. M. (1982). Sulfur speciation and associated trace metals ( $\mathrm{Fe}, \mathrm{Cu}$ ) in the pore waters of Great Marsh, Delaware. Geochim. cosmochim. Acta 46: 453-464

Burns, R. C., Hardy, R. W. F. (1975). Nitrogen fixation in bacteria and higher plants. Springer-Verlag, New York

Butler, J. N. (1964). Ionic equilibrium: a mathematical approach. Addison-Wesley, Reading, Mass.

Capone, D. G. (1983). Benthic nitrogen fixation. In: Carpenter, E. J., Capone, D. G. (ed.) Nitrogen in the marine environment. Academic Press, New York, p. 105-137

Capone, D. G., Taylor, B. F. (1980). $\mathrm{N}_{2}\left(\mathrm{C}_{2} \mathrm{H}_{2}\right)$ fixation in the rhizosphere of Thalassia testudinum. Can. J. Microbiol. 26: $998-1005$

Capone, D. G., Reese, D. D., Kiene, R. P. (1983). Effects of metals on methanogenesis, sulfate reduction, carbon dioxide evolution, and microbial biomass in anoxic salt marsh sediments, Appl, environ. Microbiol. 45: 1586-1591

Carmody, D. J., Pearce, J. B., Yasso, W. E. (1973). Trace metals in sediments of New York Bight. Mar. Pollut. Bull. 4: $132-135$

Delaune, R. D., Patrick, Jr., W. H. (1980). Nitrogen and phosphorus cycling in a Gulf Coast Salt Marsh. In: Kennedy, V. S. (ed.) Estuarine perspectives. Academic Press, New York, p. 143-151

Diekert, G., Klee, B., Thauer, R. K. (1980). Nickel, a component of factor $F_{430}$ from Methanobacterium thermoautotrophicum. Arch. Microbiol. 124: 103-106 
Farmer, J. G. (1983). Metal pollution in marine sediment cores from the west coast of Scotland. Mar. environ. Res. 8: 1-28

Gadd, G. M., Griffiths, A. J. (1978). Microorganisms and heavy metal toxicity, Microb. Ecol. 4: 303-317

Giblin, A. E., Bourg, A., Valiela, I., Teal, J. M. (1980). Uptake and losses of heavy metals in sewage sludge by a New England salt marsh. Am. J. Bot. 67: 1059-1068

Greig, R. A., McGrath, R. A. (1977). Trace metals in sediments of Raritan Bay. Mar. Pollut. Bull. 8: 188-192

Haines, E., Chalmers, A., Hanson, R., Sherr, B. (1977). Nitrogen pools and fluxes in a Georgia salt marsh. In: Wiley, M. (ed.) Estuarine processes, Vol. 2. Academic Press, New York, p. 241-254

Henriksen, K., Hansen, J. I., Blackburn, T. H. (1981). Rates of nitrification, distribution of nitrifying bacteria, and nitrate fluxes in different types of sediment from Danish waters. Mar. Biol. 61: 299-304

Horne, A. J., Goldman, C. R. (1974). Suppression of nitrogen fixation by blue-green algae in a eutrophic lake with trace additions of copper. Science, N. Y. 183: 409-411

Kaspar, H. F. (1982). Denitrification in marine sediments: measurement of capacity and estimate of in situ rate. Appl. environ. Microbiol. 43: 522-527

Kaspar, H. F., Tiedje, J. M., Firestone, R. B. (1981). Denitrification and dissimilatory nitrate reduction to ammonium in digested sludge. Can. J. Microbiol. 27: 878-885

King, G. M., Klug, M. J., Wiegert, R. G., Chalmers, A. G. (1982). Relation of soil water movement and sulfide concentration to Spartina alterniflora production in a Georgia salt marsh. Science, N. Y. 218: 61-63

Khalid, R. A., Patrick Jr., W. H., Gambrell, R. P. (1978). Effect of dissolved oxygen on chemical transformations of heavy metals, phosphorus, and nitrogen in an estuarine sediment. Estuar. coast. mar. Sci. 6: 21-35

Lion, L. W., Leckie, J. O. (1982). Accumulation and transport of $\mathrm{Cd}, \mathrm{Cu}, \mathrm{Pb}$ in an estuarine salt marsh surface microlayer. Limnol. Oceanogr. 27: 111-125

Mulder, E. G., Lie, T. A., Houwers, A. (1977). The importance of legumes under temperate conditions. In: Hardy, R. W. F., Gibson, A. H. (ed.) A treatise on dinitrogen fixation, Sect. IV, Agronomy and ecology. Wiley-Interscience, New York, p. 221-242

Nedwell, D. B. (1982). The cycling of sulphur in marine and freshwater sediments. In: Nedwell, D. B., Brown, C. M. (ed.) Sediment microbiology. Academic Press, New York, p. 73-1061

Nedwell, D. B., Aziz, S. A. (1980). Heterotrophic nitrogen fixation in an intertidal saltmarsh sediment. Estuar. coast. mar. Sci. 10: 699-702

Nixon, S. W. (1981). Remineralization and nutrient cycling in coastal marine ecosystems. In: Neilson, B. J., Cronin, L. E. (ed.) Estuaries and nutrients. Humana Press, Clifton, New Jersey, p. 111-138

Oremland, R. S., Taylor, B. F. (1978). Sulfate reduction and methanogenesis in marine sediments. Geochim. cosmochim. Acta 42: 209-214

Ortner, P. B., Kreader, C., Harvey, G. R. (1983). Interactive effects of metals and humus on marine phytoplankton carbon uptake. Nature, Lond. 301: 57-59

Petrilli, F. L., Deflora, S. (1977). Toxicity and mutagenicity of hexavalent chromium on Salmonella typhimurum. Appl. environ. Microbiol. 33: 805-809

Rother, J. A., Millbank, J. W., Thornton, I. (1982). Seasonal fluctuations in nitrogen fixation (acetylene reduction) by free-living bacteria in soils contaminated with cadmium, lead and zinc. J. Soil Sci. 33: 101-113

Sherr, B. F., Payne, W. J. (1981). The effect of sewage sludge on salt-marsh denitrifying bacteria. Estuaries 4: 146-149

Smillie, R. H., Hunter, K., Loutit, M. (1981). Reduction of chromium (VI) by bacterially produced hydrogen sulphide in a marine environment. Wat. Res. 15: 1351-1354

Sorensen, J. (1978). Denitrification rates in a marine sediment as measured by the acetylene inhibition technique. Appl. environ. Microbiol. 36: 139-143

Sorensen, J. (1982). Reduction of ferric iron in anaerobic marine sediment and interaction with reduction of nitrate and sulfate. Appl. environ. Microbiol. 43: 319-324

Tam, T. Y., Knowles, R. (1979). Effects of sulfide and acetylene on nitrous oxide reduction by soil and by Pseudomonas aeruginosa. Can. J, Microbiol. 25: 1133-1138

Valiela, I., Teal, J. M. (1979). The nitrogen budget of a saltmarsh ecosystem. Nature, Lond. 280: 652-656

Van Raalte, C. D., Patriquin, D. G. (1979). Use of the „acetylene blockage" technique for assaying denitrification in a salt marsh. Mar. Biol. 52: 315-320

Van Raalte, C. D., Valiela, I., Carpenter, E. J., Teal, J. M. (1974). Inhibition of nitrogen fixation in salt marshes measured by acetylene reduction. Estuar. coast. mar. Sci. 2: 301-305

Wallace Jr., G. T. (1982). The association of copper, mercury, and lead with surface-active organic matter in coastal seawater. Mar. Chem. 11: 379-394

Ward, T. J., Young, P. C. (1981). Trace metal contamination of shallow marine sediments near a lead smelter, Spencer Gulf, South Australia. Aust. J. mar. Freshwat. Res. 32: 45-46

Williams, S. C., Simpson, H. J., Olsen, C. R., Bopp, R. F. (1978). Sources of heavy metals in sediments of the Hudson River estuary. Mar. Chem. 6: 195-213

Yeomans, J. C., Beauchamp, E. G. (1978). Limited inhibition of nitrous oxide reduction in soil in the presence of acetylene. Soil Biol. Biochem. 10: 517-519 